\title{
Petrology of impact-melt rocks at the Chicxulub multiring basin, Yucatán, Mexico
}

\author{
Benjamin C. Schuraytz \\ Virgil L. Sharpton f Lunar and Planetary Institute, 3600 Bay Area Boulevard, Houston, Texas 77058
}

Luis E. Marín Instituto de Geofísica, Universidad Nacional Autónoma de México, Coyoacan 04510, México D. F.

\begin{abstract}
Compositions and textures of melt rocks from the upper part of the Chicxulub structure are typical of melt rocks at other large terrestrial impact structures. Apart from variably elevated iridium concentrations $(<1.5$ to $13.5 \pm 0.9 \mathrm{ppb})$ indicating nonuniform dissemination of a meteoritic component, bulk rock and phenocryst compositions imply that these melt rocks were derived exclusively from continental crust and platform-sediment target lithologies. Modest differences in bulk chemistry among samples from wells located $\sim \mathbf{4 0} \mathrm{km}$ apart suggest minor variations in relative contributions of these target lithologies to the melts. Subtle variations in the compositions of early-formed pyroxene and plagioclase also support minor primary differences in chemistry between the melts. Evidence for pervasive hydrothermal alteration of the porous mesostasis includes albite, K-feldspar, quartz, epidote, chlorite, and other phyllosilicates, as well as siderophile element-enriched sulfides, suggesting the possibility that Chicxulub, like Sudbury, may host important ore deposits.
\end{abstract}

\section{INTRODUCTION}

This report presents detailed petrographic descriptions and chemical analyses of igneous-textured rocks from the Chicxulub structure in Yucatán, Mexico. A suite of observations including diagnostic evidence of shock metamorphism (Sharpton et al., 1992), isotopic signatures (Sharpton et al., 1992; Swisher et al., 1992; Blum et al,, 1993; Krogh et al., 1993), and geophysical constraints (Sharpton et al., 1993) provide compelling arguments that the Chicxulub structure is a buried multiring basin formed by hypervelocity impact and is the source of ejecta distributed worldwide at the Cretaceous-Tertiary (K-T) boundary, 65 m.y. ago (Alvarez et al., 1980). Nevertheless, some workers dispute its impact origin and continue to proffer opinions that the Chicxulub structure is a volcanic sequence of Late Cretaceous age (Meyerhoff et al., 1994). These opinions are based in part on early well-log descriptions of andesite and bentonitic breccia-now recognized as a sequence of impact-melt rock and suevitic breccia (Sharpton et al., 1992). The stratigraphic sequence involved in the impact event includes $\sim 2.5 \mathrm{~km}$ of platform sediments over crystalline basement of continental affinity (Lopez Ramos, 1975; Sharpton et al., 1994a). With estimates of its diameter ranging from 180 to $300 \mathrm{~km}$, (Hildebrand et al., 1991; Sharpton et al., 1993), Chicxulub is clearly one of the largest and best-preserved impact structures on Earth. Consequently, it provides a unique opportunity to observe, on a variety of scales, the effects of processes involved in the formation and evolution of large impact. melt sheets, as well as the relation between these main melt volumes and globally dispersed ejecta.

At present, however, samples of melt rock from within the structure are limited, and it is unclear whether any of them represent material from a continuous melt sheet. Our samples were obtained from drill cores recovered from Petróleos Mexicanos exploratory wells Chicxulub $1(\mathrm{C} 1)$ and Yucatán 6 (Y6), located $\sim 40 \mathrm{~km}$ apart near the center of the structure (Sharpton et al., 1993). Specifically, they comprise material from the C1-N10 interval, 1393-1394 m below sea level (bsl), and from intervals Y6-N17 (1295.5-1299 $\mathrm{m} \mathrm{bsl}$ ) and Y6-N19 (1377$1379.5 \mathrm{~m} \mathrm{bsl}$ ). Although initial studies of samples from these and the adjacent C1-N9 intervals have been published (Hildebrand et al., 1991; Kring and Boynton, 1992; Swisher et al., 1992; Sharpton et al., 1992; Blum et al., 1993; Koeberl et al., 1994), a coordinated evaluation of whole-rock major and trace element chemical analyses together with compositional variations among the principal liquidus phases has not been published previously. Here we present additional geochemical and textural characterizations of those Chicxulub melt rocks currently available to us in order to provide further constraints on their formation and evolution

\section{PETROGRAPHY}

Melt-rock textures of the three core intervals are distinctly different (Fig. 1), most notably in the size and abundance of undigested clasts, variations in color, grain size, and porosity of the matrix, and evidence of alteration. Clasts in Y6-N17 constitute $-35 \%$ of the rock and show a bimodal size distribution dominated by single mineral fragments and polycrystalline domains of highly deformed, recrystallized quartz and feldspar $<1 \mathrm{~mm}$ in length, with larger fragments up to $4 \mathrm{~mm}$ (Fig. 1A). Subhedral, stubby to skeletal pyroxene prisms $(10-70$ $\mu \mathrm{m}$ long) enclosed in quartz (some bordered by anhydrite) form coronas surrounding quartz clasts and pervade the interiors of more highly disrupted granitic domains, with aggregates up to $1 \mathrm{~mm}$. In some extreme instances, a glomerophyric cluster of pyroxene is the only visible remains. Such pyroxenes are confined to individual quartz and quartz-rich granitic fragments and are notably absent around feldspar. Micrographic intergrowths of pyroxene, magnetite, and vermicular feldspar form clotlike domains in the matrix and probably represent melted but unassimilated ferromagnesian basement-clast components. The matrix comprises subhedral to euhedral microphenocrysts of pyroxene and plagioclase ranging from 5 to $15 \mu \mathrm{m}$ in length, set in a porous, cryptocrystalline mesostasis (Fig. 1B). Minor phases include magnetite; ilmenite; apatite; sphene; sulfides; a hydrous, iron- and magnesium-rich aluminosilicate; and trace amounts of barite and halite. Anhydrite constitutes $\sim 8 \%$ of the thin section, mostly as veins and cavity fillings.

Samples from the Y6-N19 interval reveal a melt matrix breccia (Fig. 1C) containing 2-11 cm angular to subrounded melt clasts of at least two texturally distinct types. The dominant melt clast type is very similar to the surrounding matrix, and in some cases the boundary between them is difficult to discern. This material is also essentially similar to Y6-N17, consisting of 5-15- $\mu \mathrm{m}$-long, subhedral to euhedral pyroxene and plagioclase in a cryptocrystalline quartzofeldspathic mesostasis showing variable porosity. Minor constituents include magnetite, ilmenite, apatite, sphene, zircon, sulfides, and a rare earth element (REE)-rich phase. In some regions, lath-shaped pyroxene and plagioclase microphenocrysts show a welldeveloped trachytic texture interfingering with regions of more randomly oriented grains, which may also be aligned but in a direction oblique to the plane of the thin section. These alignments appear to be flow foliations reflecting turbulent mingling of melt. In contrast to Y6-N17, undigested sil- 


\section{Information for Contributors to Geology}

Geology articles should be short, innovative, provocative, and of interest to a broad audience. Authors should indicate in their cover letter how their paper fulfills these criteria. We encourage submission of articles in all fields of geology, including hydrogeology, planetary geology, and engineering geology.

The length of articles should not exceed four printed pages (one Geology page is equal to approximately four double-spaced pica-type manuscript pages, or 7500 characters-letters and spaces between words), including abstract, references, tables, illustrations at smallest readable size, and captions. Submitted manuscripts determined to be longer than four printed pages may be returned to the author for shortening before reviews are solicited. However, authors are encouraged to submit additional, supporting data with their manuscripts for review and inclusion in the GSA Data Repository if the article is published in Geology. Although supporting data are not published, they are available, at no cost, upon written request to GSA.

Authors are encouraged to submit the names and addresses of three individuals who would provide objective, rigorous reviews of the manuscript. Three copies of the manuscript and figures must be submitted, with a cover letter including a statement that the paper has not been previously published and is not and will not be submitted for publication elsewhere while it is in review for Ceology. Two of the manuscript copies will go to the reviewers. The manuscript, including figure captions and references, must be double spaced, typed on one side only on paper measuring $8 \frac{1}{2} \times 11$ in. $(21.5 \times 28 \mathrm{~cm})$, with 1 -in. $(2.5-\mathrm{cm})$ margins. Send three glossy prints of any photograph(s) among the illustrations. Send copies of line drawings, not originals. For reference style, check a recent issue of Geology or write to the Editorial Department for a copy of "Information for Contributors."

Full color illustrations can be published in selected Geology issues at a cost of $\$ 750$ per page to authors.

Comments for Forum should focus on the broad assertions in the original article or their implications. Comments should be of broad interest to our general readership; those that are too specific or personal will be returned. Although we encourage Comments on the broader aspects of original articles, Comments should not be take-off points for topics that should be covered by complete, independent articles. A Comment (three copies) must be submitted within six months of publication of the original article. The Geology editor will send a copy of the Comment to the original author for a Reply, which should be submitted to GSA within one month. No Comment or Reply should exceed one printed page, including references, figures, and tables (about 7500 characters of text equal one printed page). Comment and Reply manuscripts must be double spaced.

Manuscripts are copy-edited after acceptance. The author will not see galleys or page proofs.

Send manuscripts to Geology, Geological Society of America, 3300 Penrose Place, P.O. Box 9140, Boulder, CO 80301 . Include your phone and fax numbers.

GSA requests voluntary page contributions of $\$ 125$ per printed page for Geology articles. Acceptance and scheduling of articles are not contingent upon payment of page contributions.

\section{Special Reports}

For rapid publication of new results of extremely broad interest, Geology offers an expedited review and publication process-3-4 months from manuscript submission to publication. Authors must contact one of the Geology co-editors before submission to determine if a topic would qualify for a Special Report. The co-editors' names and telephone numbers are at the top of the contents page of each Geology issue. Special Report authors must follow the guidelines above for manuscript length and format.

\section{Have a Good Cover Photo for Geology?}

We want color photos or other images to use on the cover of Geology. Photos must be of high technical quality and tell an interesting geologic story, supplemented only with a short explanatory paragraph. Submit a color transparency and one color print, which should be at least $5^{\prime \prime} \times 7$ ". Include a short paragraph, typed double spaced, explaining the geologic interest of the photo and including a credit line for it. Note that cover photos are not considered part of an article published in Geology. If a cover image is related to an article in that issue, the only reference to that fact is in the caption for the cover. Send items and your name and address to Geology, 3300 Penrose Place, P.O. Box 9140, Boulder, CO 80301. 
Figure 1. A: Y6-N17 melt rock, cut by anhydrite vein (left), with abundant silicate basement clasts (plane light, width of view $=15 \mathrm{~mm}$ ). B: Y6-N17 matrix showing pyroxene (Py) and plagioclase (PI) microphenocrysts, in porous albitic (Ab) mesostasis (backscattered-electron image, width of view $=200 \mu \mathrm{m})$. C: Y6-N19 melt breccia (width of view $=18 \mathrm{~cm}$ ). D: $\mathrm{C}_{1}$ N10 melt rock with finer grained melt clasts (plane light, width of view $=15 \mathrm{~mm}$ ). E: C1-N10 plagioclase phenocryst (PI, $\mathbf{A n}_{58.1} \mathbf{A b}_{39.5} \mathrm{Or}_{1.4}$ ), partially replaced by albite (Ab $\mathrm{An}_{0.4} \mathrm{Ab}_{\mathbf{9 9 . 3}} \mathrm{Or}_{0.3} \mathrm{)}$, and mesostasis $\mathrm{K}$-feldspar (Kf, $A n_{1,8} A b_{12,} \mathrm{Or}_{25.5}$ ), quartz (Qz), and epidote (Ep) (backscattered-electron image, scale bar represents $100 \mu \mathrm{m}$ ).

icate basement clasts in Y6-N19 are typically larger (up to $8 \mathrm{~mm}$ diameter) and show clear examples of planar deformation features. Also, in addition to veins and cavity fillings, there are undigested but recrystallized angular fragments of anhydrite. As in Y6-N17, pyroxene intergrown with quartz commonly mantles partially digested quartz and granitic fragments.

The other melt clast type in Y6-N19 appears to be derived from a granitic or granodioritic gneiss protolith that was not disaggregated but in which most of the silicate mineral constituents were melted. These clasts are predominantly anhedral quartz and feldspar domains (up to $4 \mathrm{~mm}$ ), which deformed plastically around isolated fragments of undigested shocked quartz, and elongate, irregular dense regions that appear opaque in transmitted light. Reflectedlight and backscattered-electron images reveal that these dense regions are melt domains composed of cryptocrystalline pyroxene with a vermicular intergrowth of feldspar and minute oxides. In some thin sections, these dense, elongate regions are roughly aligned and may reflect a relict foliation of ferromagnesian minerals in the protolith. Other opaque regions consist of anastomosing networks of skeletal ilmenite, intergrown with sphene. The interstices of the silicate domains include brownish, fluidal-textured regions, some showing spherulitic textures typical of devitrification. The anhedral quartz domains are commonly surrounded by pyroxene prisms up to $75 \mu \mathrm{m}$ in length, whereas the feldspar domains, which have nonstoichiometric compositions ranging from $\mathrm{An}_{48} \mathrm{Ab}_{49} \mathrm{Or}_{3}$ to $\mathrm{An}_{26} \mathrm{Ab}_{46} \mathrm{Or}_{28}$, are mantled by a similarly nonstoichiometric but more potassic composition of $\mathrm{An}_{2} \mathrm{Ab}_{10} \mathrm{Or}_{88}$.

C1-N10 (Fig. 1D) is distinct from the Y6 samples with respect to both the virtual absence of unmelted clasts and the coarser grain size of the matrix. The matrix is dominated by an intersertal arrangement of subhedral to euhedral pyroxene up to $0.7 \mathrm{~mm}$
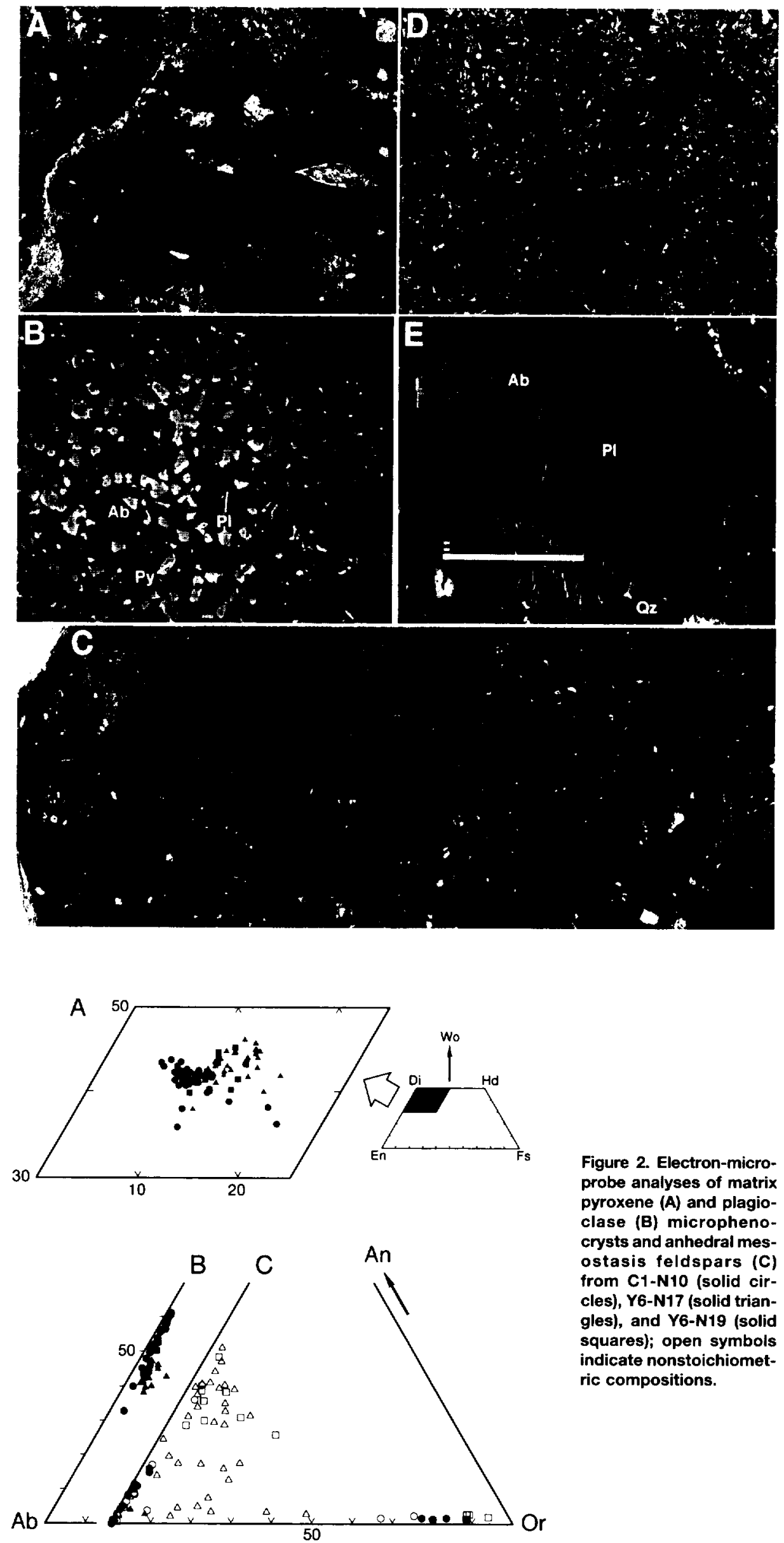

Figure 2. Electron-microprobe analyses of matrix pyroxene (A) and plagioclase (B) microphenocrysts and anhedral mesostasis feldspars (C) from $\mathrm{C} 1-\mathrm{N} 10$ (solid circles), Y6-N17 (solid triangles), and Y6-N19 (solid squares); open symbols indicate nonstoichiometric compositions. 
and plagioclase showing a range of crystal morphologies from skeletal, swallowtail, and box-work outlines to lath-shaped prisms up to $1 \mathrm{~mm}$ in length. Some of these pyroxene and plagioclase phenocrysts are twinned and slightly zoned toward their margins. The mesostasis is a porous intergrowth of sodic and potassic feldspar and quartz, showing spherulitic texture in some regions. Minor phases include magnetite; apatite; sphene; pyrite; chalcopyrite; chlorite; epidote; calcite; and a hydrous, iron- and magnesiumrich aluminosilicate. The matrix also contains angular or rounded clasts of much finer grained melt rock (Fig. 1D). The minerals in these melt fragments are essentially the same as those in the host, although the smaller pyroxene $(<100 \mu \mathrm{m})$ and plagioclase $(<50 \mu \mathrm{m})$ phenocrysts impart a more granular texture and no potassic feldspar was observed in the mesostasis, which is less porous.

\section{CHEMISTRY}

Whole-rock major element compositions (Table 1) are similar to medium- to high-K calc-alkalic andesite to dacite (Gill, 1981). Results for Y6-N17 generally agree with those published elsewhere (Hildebrand et al., 1991). As expected from the variegated lithology of the Y6-N19 breccia, these subsamples exhibit some compositional variability, but on average are significantly lower in $\mathrm{SiO}_{2}$ and $\mathrm{Na}_{2} \mathrm{O}$ and higher in $\mathrm{CaO}$ than either $\mathrm{Y} 6-\mathrm{N} 17$ or $\mathrm{C} 1-\mathrm{N} 10$.

Trace element concentrations are also similar to those of andesites, with the only significant departure being anomalous Ir enrichments in several of the specimens. Concentrations in two fragments of $\mathrm{C} 1-\mathrm{N} 10$ and duplicate splits of C1-N10-2 and Y6-N19-R are identical within analytical uncertainties except for $\mathrm{Ir}$ and $\mathrm{Au}$; the $\mathrm{C} 1-\mathrm{N} 10$ analyses also show heterogeneity for $\mathrm{Cr}$ and $\mathrm{Co}$ ( $\mathrm{Ta}$ ble 1). The Y6-N19 subsamples span nearly the total range of variation among specimens from the three core intervals for many elements. The $\mathrm{C} 1-\mathrm{N} 10$ samples exhibit modest enrichments in $\mathrm{Co}, \mathrm{Zr}, \mathrm{Hf}, \mathrm{Ta}$, and heavy REEs (HREEs), and lower $\mathrm{Sr}$ relative to the Y6 specimens.

Pyroxene phenocryst compositions in our samples from all three core intervals are exclusively augite and, predictably, lie within the range of augite core compositions $\left(\mathrm{En}_{40-55} \mathrm{Wo}_{38-50} \mathrm{Fs}_{7-20}\right)$ in andesites (Gill, 1981). The coarser grains of the $\mathrm{Cl}-\mathrm{N} 10$ matrix show an iron-enrichment trend (Fig. 2A), with modest, corresponding increases in $\mathrm{Na}_{2} \mathrm{O}, \mathrm{TiO}_{2}$, and $\mathrm{MnO}$. These variations also characterize the extent of core to rim zoning within individual phenocrysts, the increase of Fe occurring abruptly near crystal margins. Compositions within the finer-grained melt clasts in C1-N10 form a relatively tight cluster with an average composition of $\mathrm{En}_{44} \mathrm{Wo}_{42} \mathrm{Fs}_{9}$. Our analyses of augite microphenocrysts in $\mathrm{Y} 6-\mathrm{N} 17$ and Y6-N19 yield an average $\left(\mathrm{En}_{43} \mathrm{Wo}_{45} \mathrm{Fs}_{12}\right)$ consistent with those of Kring and Boynton (1992), but contrast with the fassaitic compositions reported by Cedillo et al. (1994). Compared to those in $\mathrm{C} 1-\mathrm{N} 10$, augites in Y6-N17 and Y6-N19 are generally lower in $\mathrm{SiO}_{2}$ and molar $\mathrm{Mg} /(\mathrm{Mg}+\mathrm{Fe})$, and higher in $\mathrm{Na}_{2} \mathrm{O}, \mathrm{TiO}_{2}$, and $\mathrm{MnO}$. Apart from slightly higher $\mathrm{SiO}_{2}$, there are no significant compositional differences between augite microphenocrysts in the groundmass and those bordering undigested quartz clasts.

Although the feldspar mineral assemblage as a whole shows considerable chemical variability, plagioclase is the only feldspar present as a phenocryst. Consequently, those early-formed plagioclase crystals that have not suffered extensive alteration (Fig. 2B) define a more restricted range of variation (andesine to labradorite) and thus are compositionally as well as texturally distinct from feldspars in the surrounding mesostasis (Fig. 2C). With decreasing An content $\left(\mathrm{An}_{59-32}\right)$, coarser plagioclase phenocrysts in the C1-N10 matrix show a corresponding monotonic decrease in $\mathrm{MgO}$, and an initial Fe-enrichment trend that attains a maximum at $\mathrm{An}_{50}$, followed by a decrease in FeO. Plagioclase phenocrysts within the finer-grained melt clasts of $\mathrm{C} 1$ N10 tend to be more calcic, relatively constant in $\mathrm{MgO}$, and higher in $\mathrm{FeO}$, with an Fe-enrichment maximum at $\mathrm{An}_{56}$. Analyses of Y6-N17 and Y6-N19 are generally higher in $\mathrm{K}_{2} \mathrm{O}$ and $\mathrm{FeO}$ and lower in $\mathrm{MgO}$ than those of C1-N10 and are consistent with the average composition of groundmass plagioclase in Y6-N17 published previously (Kring and Boynton, 1992).

The mesostasis of C1-N10 (Fig. 2C) includes alkali feldspar and plagioclase ranging from oligoclase to pure albite. An example of the textural relations of these feldspars to a euhedral plagioclase phenocryst (Fig. 1E) shows that albite forms at the expense of the calcic host, which in turn is surrounded by anhedral K-feldspar intergrown with quartz, epidote, minute opaque minerals, and a cryptocrystalline aluminosilicate that appears to be a devitrification product of glass. Feldspar compositions in the mesostasis of Y6-N17 are highly variable (Fig. 2C); however, with the exception of albite, our analyses indicate that they are nonstoichiometric. These anhedral, cationdeficient phases fill the interstices of the andesine and augite microphenocrysts, some of which protrude into the ubiquitous drusy cavities (Fig. 1B). Thermodynamic considerations together with textural relations be- tween early-formed phases and the porous mesostasis suggest to us that, as in $\mathrm{C} 1-\mathrm{N} 10$, the albite results from secondary alteration (Schuraytz and Sharpton, 1993). Similar compositional and textural relations characterize feldspar variations in the Y6-N19 mesostasis, although the variations in porosity are more extreme.

\section{DISCUSSION}

Except for anomalous Ir enrichments in several specimens attributed to nonuniform dissemination of the projectile (Sharpton et al., 1992; Schuraytz and Sharpton, 1994), our analyses suggest that the melts were derived exclusively from continental crust and platform-sediment target lithologies, with no evidence of a significant mantle or oceanic crustal signature. These results are supported by $\mathrm{Sr}, \mathrm{Nd}, \mathrm{O}$, and $\mathrm{Os}$ isotopic studies on the C1-N10 samples with regard to both the continental affinity of the target rocks (Blum et al., 1993) and the heterogeneous distribution of up to $3 \%$ meteoritic contamination (Koeberl et al., 1994). Considering current constraints on excavation depth (15-25 km) of the Chicxulub impact event (Sharpton et al., 1994b) and the potential lithologic diversity within this volume, the observed chemical variability is rather small, in keeping with the gross compositional homogeneity of melt rocks from other terrestrial impact structures, such as Manicouagan (Grieve and Floran, 1978) and West Clearwater (Simonds et al., 1978). However, given that these few specimens represent an inordinately small sampling of the upper $\sim 100 \mathrm{~m}$ of known melt rock, the limited compositional range should be regarded as tentative, as should comparisons with smaller structures where the upper part of the melt sequence has been eroded. The small variations in bulk composition (e.g., $\mathrm{SiO}_{2}, \mathrm{CaO}, \mathrm{Na}_{2} \mathrm{O}, \mathrm{Sr}$, and HREEs) suggest that, compared to those from C1-N10, the melt rocks from $\mathrm{Y} 6$ assimilated a greater proportion of platform-sediment target rocks relative to silicate basement. Compositional differences among augite and plagioclase phenocrysts (the principal silicate liquidus phases) also imply primary variations in melt chemistry. The inverse correlation between clast abundance and matrix grain size (cf. Figs. 1A and 1D) indicates a substantial difference from site to site in the thermal regimes of the melts; this difference, together with the compositional differences, suggests that the C1-N10 samples were derived from a zone of deeper melting and protracted cooling.

Although the phenocrysts preserve clear evidence of igneous crystallization, it appears that secondary mineralization due to percolation of hydrothermal fluids through 


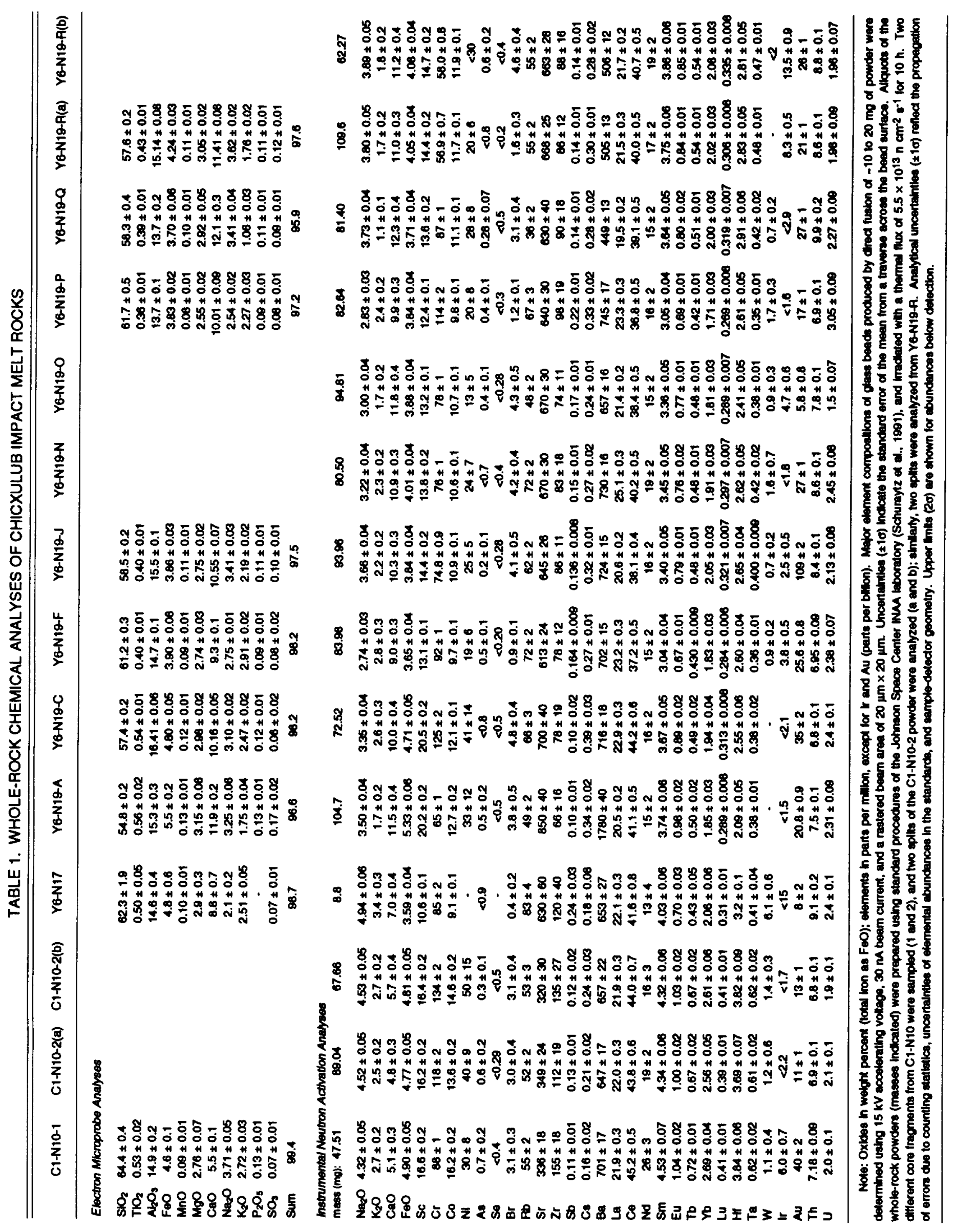



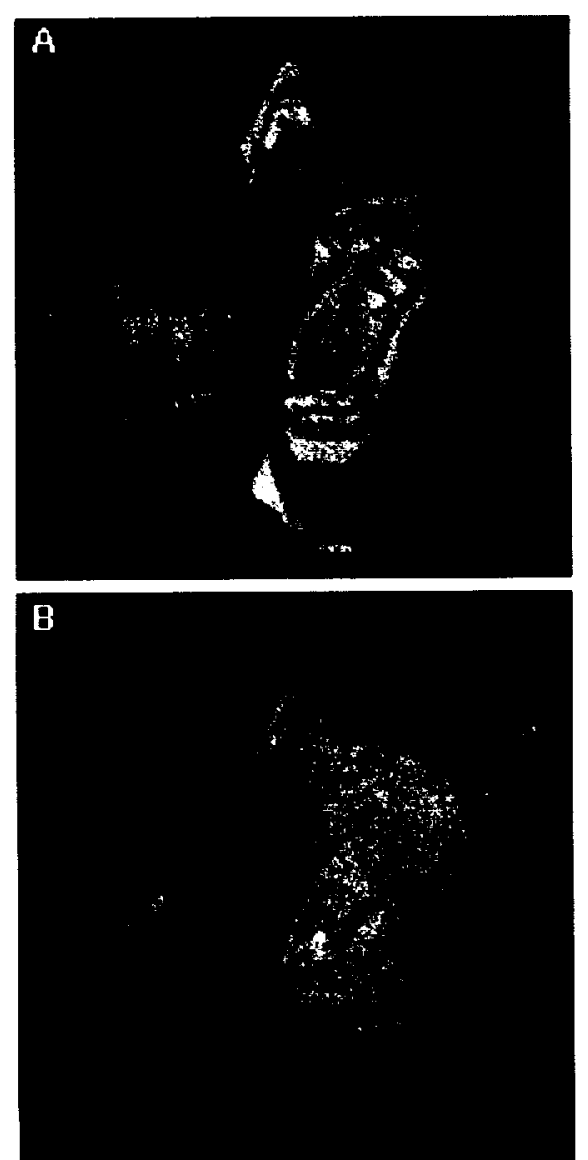

Figure 3. X-ray maps showing oscillatory zoning of $\mathrm{Co}_{(\mathrm{A})}$ and $\mathrm{Ni}(\mathrm{B})$ in pyrite from $\mathrm{C}_{1}-\mathrm{N} 10$ (width of view $=150 \mu \mathrm{m}$ ). Microprobe analy ses reveal that zone of highest Ni $(1.1 \mathrm{wt} \%)$ is relatively depleted in Co $(0.6 \mathrm{wt} \%)$, whereas highest Co $(3.9 \mathrm{wt} \%)$ corresponds to $0.2 \mathrm{wt} \%$ Ni.

the porous mesostasis was an integral process in the evolution of these rocks. All our specimens show some level of alteration, although ${ }^{40} \mathrm{Ar} /{ }^{34} \mathrm{Ar}$ determinations indicate that $\mathrm{C} 1-\mathrm{N} 10$ is least affected (Sharpton et al., 1992). Kring and Boynton (1993) argued that evidence of hydrothermal alteration in Y6-N17 is limited to quartz and possibly anhydrite veins. Despite their claims to the contrary, the melt-rock groundmass is pervasively affected by alteration. Even the least altered samples from $\mathrm{C} 1-\mathrm{N} 10$ contain anhedral albite $\left(\geq A b_{(s)}\right)$, K-feldspar, quartz, epidote, chlorite, and yet-to-be determined phyllosilicates, as well as pyrite and chalcopyrite. The pyrites are significantly enriched in $\mathrm{Co}, \mathrm{Ni}, \mathrm{Au}, \mathrm{As}$, and $\mathrm{Sb}$ (Schuraytz and Sharpton, 1994; Schuraytz et al., 1994) and show oscillatory zoning (Fig. 3) similar to pyrites observed in hydrothermal ore deposits (Fleet et al., 1989), indicating episodic variations in the composition of circulating fluids over the course of sulfide-mineral growth.

At the Sudbury structure, Ontario, the breccias and melt bodies within the Onaping Formation exhibit many textural and mineralogical similarities to the Chicxulub rocks described above, including extensive alteration of plagioclase to albite, secondary epidote, chlorite, and minor, but ubiquitous sulfide mineralization (Muir and Peredery, 1984). Muir noted that sulfides in the sublayer of the Sudbury Igneous Complex are similar to those occurring throughout the Onaping Formation, whereas Peredery regarded the majority of these sulfides to be due to secondary replacement. The origin of the metals in these sulfides is unknown; however, Allen et al. (1982) cited secondary silicate and clay mineralization within the Onaping as evidence of impact-induced hydrothermal alteration. Although the relation between sulfide genesis within the Onaping Formation and other parts of the Sudbury Igneous Complex is not completely understood, potential similarities between sulfide mineralization in the Onaping and in melt rocks from Chicxulub may signal the possibility of more extensive strategic resources elsewhere at the Chicxulub structure.

\section{ACKNOWLEDGMENTS}

We thank D. W. Mittlefehldt and S.-R. Yang for consultation and use of analytical facilities at the NASA Johnson Space Center: A. Treiman. R. Anderson, and an anonymous referee for critical reviews; and $S$. Hokanson and D. Rueb for graphics support. The Lunar and Planetary Institute is operated by Universities Space Research Association under contract (NASW 4574) with the National Aeronautics and Space Administration. Lunar and Planetary Institute contribution 834.

\section{REFERENCES CITED}

Allen, C. C., Gooding, J. L., and Keil, K., 1982, Hydrothermally altered impact melt rock and breccia: Contributions to the soil of Mars: Journal of Geophysical Research, v. 87, p. 10,083-10,101.

Alvarez, L. W., Alvarez, W., Asaro, F., and Michel, H. V., 1980. Extraterrestrial cause for the Cretaceous-Tertiary extinction: Science, v. 208, p. 1095-1108.

Blum, J. D., Chamberlain, C. P., Hingston, M. P., Koeberl, C., Marin, L. E., Schuraytz, B. C., and Sharpton, V. L., 1993, Isotopic comparison of $\mathrm{K} / \mathrm{T}$ boundary impact glass with melt rock from the Chicxulub and Manson impact structures: Nature, v. 364, p. $325-327$

Cedillo P., E., Claeys, P., Grajales N., J. M., and Alvarez, W., 1994, New mineralogical and chemical constraints on the nature of target rocks at the Chicxulub crater, in Conference on new developments regarding the KT event and other catastrophes in Earth history [abs.]: Houston, Texas, Lunar and Planetary Institute, LPI Contribution 825, p. 20-21.

Fleet, M. E., MacLean, P. J., and Barbier, J., 1989, Oscillatory-zoned As-bearing pyrite from stratabound and stratiform gold deposits: An indicator of ore fluid evolution, in Keays, R. R., et al. eds., The geology of gold deposits: The perspective in 1988 : Economic Geology Monograph 6, p. 356-362.

Gill, J. B., 1981, Orogenic andesites and plate tectonics: Berlin. Springer-Verlag, $390 \mathrm{p}$.

Grieve, R. A. F., and Floran, R. J., 1978, Manicouagan impact melt, Quebec 2. Chemical interrelations with basement and formational processes: Journal of Geophysical Research, v. 83, p. 2761-2771.

Hildebrand, A. R., Penfield, G. T., Kring, D. A., Pilkington, M., Camargo Z., A., Jacobsen, S. B., and Boynton, W V., 1991, Chicxulub crater: A possible Cretaceous/Tertiary boundary impact crater on the
Yucatán peninsula, Mexico: Geology, v. 19, p. $867-871$.

Koeberl, C., Sharpton, V. L., Schuraytz, B. C., Shirey, S. B., Blum, J. D., and Marín, L. E., 1994, Evidence for a meteoritic component in impact melt rock from the Chicxulub structure: Geochimica et $\operatorname{Cos}$ mochimica Acta, v. 58, p. 1679-1684.

Kring, D. A., and Boynton, W. V., 1992, Petrogenesis of an augite-bearing melt rock in the Chicxulub structure and its relationship to $\mathrm{K} / \mathrm{T}$ impact spherules in Haiti: Nature, v. 358, p. 141-144

Kring, D. A., and Boynton, W. V., 1993, K/T melt glasses: Nature, v. 363, p. 503-504.

Krogh, T. E., Kamo, S. L., Sharpton, V. L., Marín, L. E. and Hildebrand, A. R., 1993, U-Pb ages of single shocked zircons linking distal $K / T$ ejecta to the Chicxulub crater: Nature, v. 366, p. 731-734.

Lopez Ramos, E., 1975, Geological summary of the Yucatán Peninsula, in Nairn, A. E. M., and Stehli, F. G., eds., The ocean basins and margins, Volume 3-The Gulf of Mexico and the Caribbean: New York. Plenum, p. 257-282.

Meyerhoff, A. A., Lyons, J. B., and Officer, C. B., 1994 Opinion: Chicxulub structure: A volcanic sequence of Late Cretaceous age: Geology, v. 22, p. 3-4.

Muir, T. L., and Peredery, W. V., 1984, The Onaping Formation, in Pye, E. G., et al., eds., The geology and ore deposits of the Sudbury structure: Ontario Geological Survey Special Volume 1, p. 139-210.

Schuraytz, B. C., and Sharpton, V. L., 1993, ChicxulubK/T melt complexities: Nature, v. 362, p. 503-504

Schuraytz, B. C, and Sharpton, V. L.. 1994, Siderophileelement distribution in Chicxulub melt rocks: Forensic chemistry on the K-T smoking gun, in Conference on new developments regarding the K-T event and other catastrophes in Earth history [abs.] Houston, Texas, Lunar and Planetary Institute Contribution 825 , p. 106-108.

Schuraytz, B. C. O'Connell, S. B., and Sharpton, V. L. 1991, Iridium and other trace element measurements from the Cretaceous/Tertiary boundary, ODP Site 752, Broken Ridge, Indian Ocean, in Weissel, J. Pierce, J., Taylor, E. Alt, J., et al., Proceedings of the Ocean Drilling Program, scientific results, Volume 121: College Station, Texas, Ocean Drilling Program, p. 913-919.

Schuraytz, B. C., Lindstrom, D. J., Martinez, R. R Sharpton, V. L., and Marín, L. E., 1994, Distribution of siderophile and other trace elements in melt rock at the Chicxulub impact structure [abs.]: Houston, Texas, Lunar and Planetary Science XXV p. $1221-1222$.

Sharpton, V. L., Dalrymple, G. B., Marin, L. E., Ryder, G. Schuraytz, B. C., and Urrutia-Fucugauchi, J., 1992, New links between the Chicxulub impact structure and the Cretaceous/Tertiary boundary: Nature, v. 359 , p. $819-821$.

Sharpton, V. L., and nine others, 1993, Chicxulub mul tiring impact basin: Size and other characteristics derived from gravity analysis: Science, v. 261 , p. $1564-1567$.

Sharpton, V. L., Marín, L. E., and Schuraytz, B. C., 1994a, The Chicxulub multiring impact basin: Evaluation of geophysical data, well logs, and drill core samples, in Conference on new developments regarding the K-T event and other catastrophes in Earth history [abs.]: Houston, Texas, Lunar and Planetary Institute Contribution 825, p. 108-110.

Sharpton, V. L., Marín, L. E., and Schuraytz, B. C. 1994b, Constraints on excavation and mixing during the Chicxulub impact event [abs.]: Houston, Texas, Lunar and Planetary Science XXV, p. 1255-1256.

Simonds, C. H., Phinney, W. C., McGee, P. E., and Cochran, A., 1978, West Clearwater, Quebec impact structure, Part I: Field geology, structure and bulk chemistry: Lunar and Planetary Science Conference, 9th, Proceedings, v. 2, p. 2633-2658.

Swisher, C. C., III, and 11 others, 1992 , Coeval ${ }^{40} \mathrm{Ar}{ }^{39} \mathrm{Ar}$ ages of 65.0 million years ago from Chicxulub crater melt rock and Cretaceous-Tertiary boundary tektites: Science, v. 257 , p. 954-958.

Manuscript received May 31, 1994

Revised manuscript received July 1, 1994

Manuscript accepted July 18, 1994 